\title{
Woody Vegetation Composition, Structure, and Community Types of Doshke Forest in Chencha, Gamo Gofa Zone, Ethiopia
}

\author{
Ayalew Sebsibe Tegene ${ }^{D},{ }^{1}$ Feleke Woldeyes Gamo, ${ }^{2}$ and Simon Shibru Cheche ${ }^{3}$ \\ ${ }^{1}$ Department of Biology, Madda Walabu University, P.O. Box 247, Bale Robe, Ethiopia \\ ${ }^{2}$ General Ethiopian Biodiversity Institute Addis Ababa, P.O. Box 30726, Addis Ababa, Ethiopia \\ ${ }^{3}$ Department of Biology, Arba Minch University, P.O. Box 21, Arba Minch, Ethiopia
}

Correspondence should be addressed to Ayalew Sebsibe Tegene; ayalseb@gmail.com

Received 11 November 2017; Accepted 20 May 2018; Published 14 October 2018

Academic Editor: Arianna Azzellino

Copyright (C) 2018 Ayalew Sebsibe Tegene et al. This is an open access article distributed under the Creative Commons Attribution License, which permits unrestricted use, distribution, and reproduction in any medium, provided the original work is properly cited.

\begin{abstract}
This study was conducted on Doshke forest in Chencha wereda, Gamo Gofa zone, South Ethiopia, with the objective of determining woody vegetation composition, structuren, and community types of woody plant species. Systematic sampling method was used to collect vegetation data. A total of 42 quadrats each with $400 \mathrm{~m}^{2}(20 \mathrm{~m} \mathrm{X} 20 \mathrm{~m})$ were established along four lines transects for woody species and regenerations. All the collected woody plant species were identified in National Herbarium of Ethiopia. Data used to describe vegetation structure were recorded from the quadrats. Sorensens's similarity coefficient and Shannon-Wiener diversity index were also used to detect similarities and to compute species diversity and evenness respectively. A total of 44 woody species belonging to 40 genera and 28 families were recorded in the forest. The family Myrsinaceae and Rubiaceae were found to exhibit the highest number of species each with 4 species. The hierarchical cluster analysis using PC-ORD version 5.0 computer programs revealed four community types, of which Maesa lanceolata-Allophylus abyssinicus community type (C2) exhibited the highest species diversity and evenness. The structural analysis of Doshke forest revealed that the density of tree species in Doshke forest decreases with increasing height and DBH classes. The forest is characterized by high density of woody species in the lower class than in the higher. The most dominant tree species recorded were Syzygium guineense, Ilex mitis, and Galiniera saxiferaga. Three layers of woody species were identified from the study of vertical stratification. Studies on the regeneration of the forest indicated that there are species that require urgent conservation measures. Generally, Doshke forest possesses many economically and ecologically important plant species. It can be considered as the biodiversity conservation center in general and the forest genetic resources conservation in particular.
\end{abstract}

\section{Introduction}

Ethiopia is known as the biodiversity hotspot and center of origin and diversification for a significant number of plants, animals, and their wild relatives due to its dramatic geological history, broad latitudinal spread, and immense altitudinal range. This variety led to the emergence of habitats that are suitable for the evolution and survival of various plants and animal species, which contributes to the overall biodiversity of the country [1]. Altitude and rainfall strongly influence Ethiopia's extraordinary range of terrestrial and aquatic ecosystems and have contributed to a high diversity and of endemism [2]. The flora of the country is very heterogeneous and estimated to contain between 6,500 and 7000 species of higher plants, of which about $12 \%$ are endemic [3].

However, the natural forest cover of the country has been diminishing over times due to various human induced pressures such as rapid population growth, extensive forest clearing for cultivation, overgrazing, and exploitation of forests for fuel wood and construction materials without replanting [4]. In addition to anthropogenic activities, forest can be affected by different environmental factors such as altitude, slope, and aspect by affecting the patterns of tree species distribution [5]. The ever-increasing demands for forest products and forestland together with the increase in human population are putting unbearable pressure on the remaining forest 
fragments [6-8]. In Ethiopian highlands, the influence of humans and their domestic animals has profoundly altered both the vegetation and the landscape and little natural highland vegetation remains today [9]. Ecological degradation including deforestation and erosion is wide spread particularly in the northern and central highlands. Though not severely degraded, the southern parts of the highlands are being increasingly affected [10].

Deforestation and degradation are the causes of forest cover loss in Ethiopia which has its roots in a cascade of events. Geometric population growth results increased rural demand for agricultural lands. This in turn led to expansion of cultivated fields at the expense of the forest. The annual rate of deforestation in Ethiopia was found to be extremely high [11]. This unprecedented deforestation rate is considered a major threat to the Ethiopian biodiversity [12] and the habitats of the 120 threatened endemic plant species of Ethiopia [13]. This apparent forest resources degradation calls for establishment and reinforcement of stringent forest resources conservation measures while designing such measures, it is in appropriate to rely only on conventional methods since inclusion of local communities and indigenous approaches is equally important in conservation endeavor.

\section{Materials and Methods}

2.1. Description of the Study Area. The study was conducted in Doshke forest which is located in Chencha wereda of Gamo Gofa, Zone of Southern Nations, Nationalities, and Peoples Regional State (SNNPRS), Ethiopia (Figure 1). Doshke forest $\left(6^{\circ} 11^{\prime} 48^{\prime \prime}-6^{\circ} 12^{\prime} 23^{\prime \prime} \mathrm{N}\right.$ and $\left.37^{\circ} 33^{\prime} 06^{\prime \prime}-37^{\circ} 33^{\prime} 53^{\prime \prime} \mathrm{E}\right)$ is a small forest patches in Chencha wereda close to Dorze town on the northwest direction. The forest belongs to moist evergreen afromontane ecosystem. It also touches the northern side of Gara-dita kebele in the wereda. It ranges in altitude from 2425 $\mathrm{m}$. to $2550 \mathrm{~m}$.a.s.l and covers an area of about 110 hectares.

About $82 \%$ of the wereda is categorized as Dega agro-ecological zone whereas the remaining $18 \%$ is categorized under Weina Dega agro-ecological zone. The maximum mean temperature varies between 18 and $26^{\circ} \mathrm{C}$ while the minimum mean temperature ranges between 11 and $13^{\circ} \mathrm{C}$. According to Meteorological data obtained from Arba Minch University Meteorological Station within six year (2005-2010), Chencha wereda obtains high rainfall in April and October with 188.5 $\mathrm{mm}$ and $194.5 \mathrm{~mm}$ mean monthly annual rainfall respectively. The lowest rainfall distribution was recorded from January to February and November to December (Figure 2). This shows that the study area has a bimodal raining distribution pattern.

The topography of Chencha wereda is mountainous, highly undulating, and rugged with poor infrastructure. There are four rivers, namely, Baso, Hare, Shaffe, and Gina with tributary springs in the wereda. Erosion is the major cause of soil degradation in the area [14]. The land which is occupied by Doshke forest is characterized by gentle slope that ascends from the South to North sides and hill foot with flat upper surface and dissected with Matse stream emerged from the forest area and one main river known as Gina River.

The total human population of Chencha wereda is 132,677 of which 117,964 are rural while 14,716 are urban dwellers [15].
The Gamo people are the major ethnic group in the wereda. The livestock number of the wereda is estimated to be 114,152 . Since the wereda has low forest resource and coverage, there is an imbalance between supply and demand for the resource [16].

Agriculture is the mainstay of the population of the wereda. As [16] stated, $90 \%$ of the total population of Chencha wereda derives its livelihood from agriculture. The farming system of the wereda is mixed farming, compromising both cropping and livestock rearing. Enset is staple crop in the particular wereda and throughout Gamo highlands. Other main crops grown in the wereda are potato, barley and wheat in the Dega Zone and Maize, sorghum, and sweet potato in the Weina Dega.

According to [12], the forest vegetation of southwest Ethiopia is the last remaining frontiers of forested landscape in the country. The region has a relatively high forest cover compared to other parts in the country. Chencha is one of the wereda in the region which is covered by some forest patches such as Nagasa forest, Ewurie forest, and Doshke forest. In addition, the land of the wereda is covered by plantation trees most importantly Bamboo and Eucalyptus. The forest is characterized by broad-leaved and evergreen trees. Even though the forest of the study area comprised many important plant species, a little conservation attention was given for forest vegetation particularly at the marginal area of the forest.

2.2. Sampling Design. A reconnaissance survey was carried out across the forest in order to obtain an impression of the site conditions, to collect information on accessibility and to determine sampling sites and sampling methods to be used for vegetation data collection. Four transects were laid systematically and the distribution of transects were made in such a way that aspects of the forest area could be covered. Accordingly, three transects were laid to the north direction and the fourth one to the west direction. A total of 42 quadrats, each with $20 \mathrm{~m}$ by $20 \mathrm{~m}\left(400 \mathrm{~m}^{2}\right)$ were established for trees, shrubs, lianas, and regenerations. Sampling plots (quadrats) were laid systematically at every $50 \mathrm{~m}$ along transect lines. Depending on the length of the transect lines, the number of the quadrats laid on each transect line varied from 7 to 14 .

2.3. Vegetation Data Collection. In each sample plot, the woody plant species (trees, shrubs, and lianas) were recorded along with the following structural attributes. Diameter was measured for every individual trees, shrubs, and lianas having $\mathrm{DBH}$ (diameter at breast height) equal or greater to 2.5 $\mathrm{cm}$ using a diameter tape. If the tree branched at breast height or below, the diameter was measured separately for the branches and averaged. Trees and shrubs with DBH less than $2.5 \mathrm{~cm}$ were counted. In cases where tree boles buttressed, diameter measurements were related to the point just above the buttress.

Height of trees and shrubs greater than or equal to $2 \mathrm{~m}$ was measured for every woody individual species with $\mathrm{DBH}$ greater than or equal to $2.5 \mathrm{~cm}$ using calibrated stick. Where slope, topography, and crown structure made it difficult 
Ethiopian Regions Map

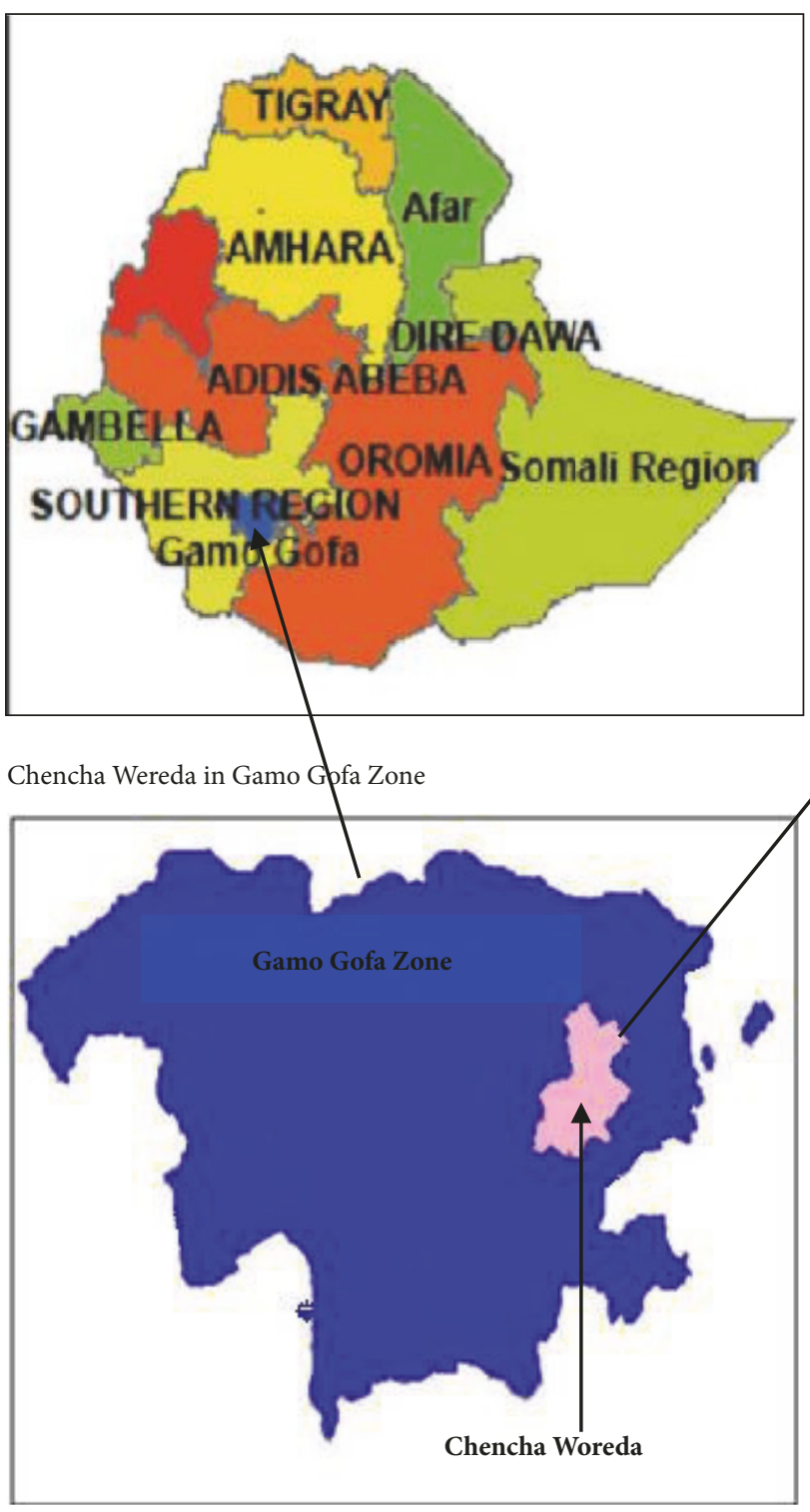

Study area and Forest location

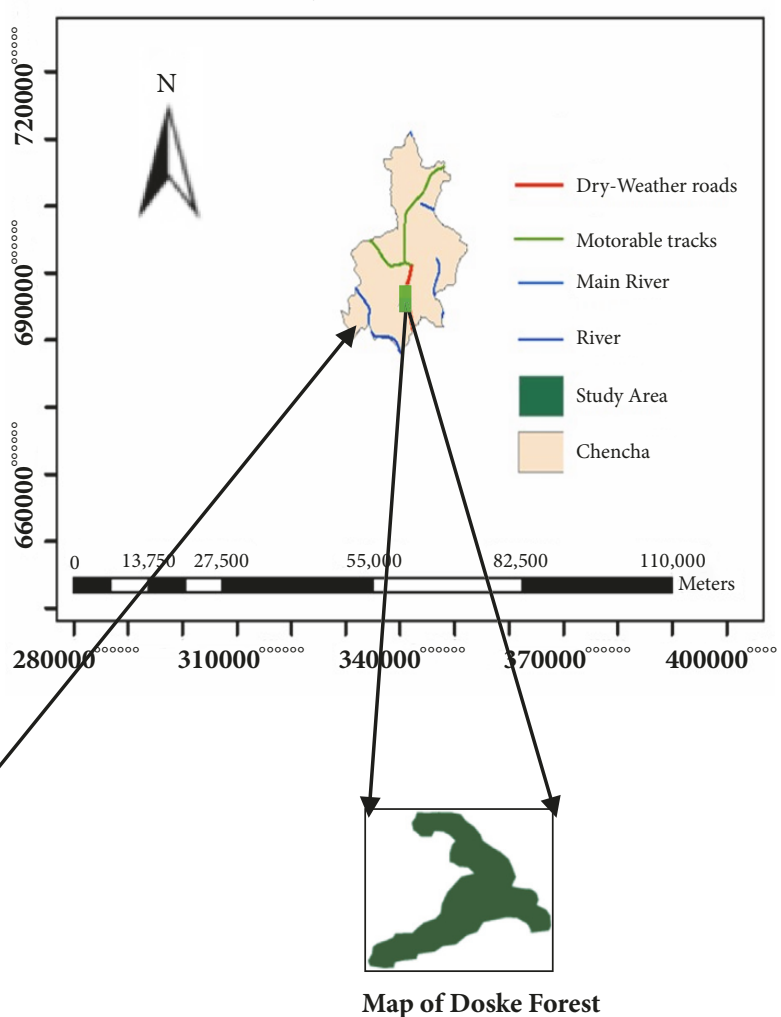

Figure 1: Map of the study area.

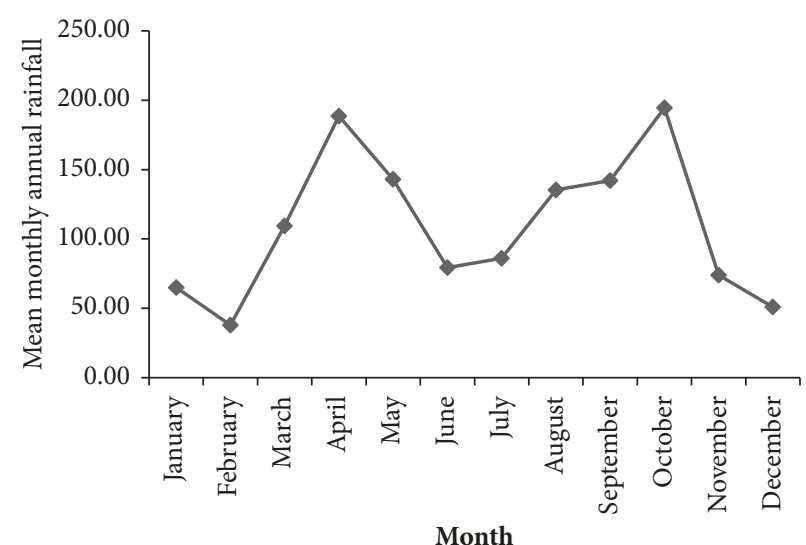

FIgURE 2: Rainfall distribution of Chencha wereda. Source: Arba Minch University Meteorological Station (2011) from 2005-2010. 
to measure height of the woody matured species, it was estimated visually. The data on number of seedlings and saplings with height less than $1 \mathrm{~m}$ for seedlings and $2 \mathrm{~m}$ for saplings with $\mathrm{DBH}$ less than $2.5 \mathrm{~cm}$ for all trees and shrubs were collected in each plot. Every woody plant species within each quadrats were recorded and coded with vernacular or scientific name as much as possible and their cover abundance (ground cover) percentage was estimated [17].

Different volumes of Flora of Ethiopia and Eritrea and field guide manuals were used to identify species in the field. Plant specimens were collected, pressed, dried and brought to the National Herbarium (ETH) at Addis Ababa University for identification. The nomenclature of the taxa follows Flora of Ethiopia and Eritrea.

\subsection{Data Analysis}

2.4.1. Plant Community Analysis. The most common multivariate technique to analyze plant communities is classification by means of cluster analysis. Cluster analysis helps to group a set of observations (plots or vegetation samples) together based on their attributes or floristic similarities $[18,19]$. Accordingly, a hierarchical cluster analysis was performed using PC-ORD for windows version 5.0 [20] to classify the vegetation into plant community types. The analysis was based on the abundance data of the species. The Relative Euclidean Distance (RED) measures using Ward's method was used in the current study to eliminate the differences in total abundance among sample units. In addition, the Ward's method was used in order to minimize the total within group mean of squares or residual sum of squares [19]. The plant community types were named after two or three dominant species selected using the relative magnitude of their mean cover abundance values.

2.4.2. Vegetation Structure Analysis. For the description of vegetation structure, tree density, frequency, height, and diameter at breast height $(\mathrm{DBH})$ distribution and basal area were used. Tree and shrub basal area and density were computed on hectare basis. Basal area (BA) is the area outline of a plant near ground surface. It is the cross-sectional area of tree stems at $\mathrm{DBH}$. Relative density, relative frequency, relative dominance, and importance value index (IVI) were calculated to determine the vegetation structure and the dominant species of the forest [21] using the following formula.

\section{Relative Density}

$$
\begin{aligned}
& =\frac{\text { Number of individuals of species }}{\text { Total number of individuals of all species }} \\
& \quad \times 100
\end{aligned}
$$

Relative Frequency

$$
=\frac{\text { Frequency of a species }}{\text { Sum of frequencies of all species }} \times 100
$$

$$
\begin{aligned}
& \text { Relative Dominance } \\
& =\frac{\text { Basal area of a single species }}{\text { Total basal area of all species }} \times 100 \\
& \text { Important Value Index (IVI) } \\
& =\text { Relative density + Relative frequency } \\
& + \text { Relative dominance. }
\end{aligned}
$$

2.4.3. Species Diversity Analysis. The Shannon-Wiener indices of diversity $\left(\mathrm{H}^{\prime}\right)$ and evenness (E) were computed to describe the species diversity and evenness of the species in the forest vegetation [22]. The Sorensen's similarity index was also used to determine the pattern of species turnover among the community types $\square 19 \square$. Shannon-Weiner index of diversity $\left(\mathrm{H}^{\prime}\right)$, evenness (E), and Sorensen's similarity index (Ss) were calculated as following Shannon \& Weaver as follows: $\mathrm{H}^{\prime}=$ $-\sum_{\mathrm{i}=1}^{\mathrm{s}}$ pi $\ln$ pi, where $\mathrm{s}=$ number of species, $\mathrm{Pi}=$ proportion of individuals or the abundance of the $\mathrm{i}^{\text {th }}$ species expressed as a proportion of the total cover, and $\ln =\log$ base.

On the other hand, evenness $(E)$ was computed as $(E)=$ $\mathrm{H}^{\prime} / \mathrm{H}^{\prime}$ max where, $\mathrm{H}^{\prime}=$ Shannon-Wiener diversity index, and $H^{\prime} \max =\ln s$, where $s$ is the number of species. The Sorensen's similarity coefficient was calculated as $(S s)=2 a /(2 a+b+c)$ where $\mathrm{a}=$ Number of species common to both samples, $\mathrm{b}=$ Number of species in sample 1 , and $c=$ Number of species in sample 2 .

\section{Results and Discussions}

3.1. Woody Species Composition of the Forest. A total of 44 woody plant species belonging to 40 genera and 28 families were recorded from 42 quadrats examined from the study area. The most dominant families of the study area are Myrsinaceae which are represented by 4 species (9.09\%) and Rubiaceae with 4 species (9.09\%). Fabaceae, Meliaceae, Rosaceae, Solanaceae, Asteraceae, and Celastraceae are represented by 2 species ( $4.55 \%$ ) each of the total floristic composition. The remaining 18 families (64.29\%) are represented by only one species (Table 1).

With regard to genera number, Rubiaceae is the most dominant with contributing 4 genera (10\%) to the total and followed by Euphorbiaceae and Myrsinaceae with each contributing 3 genera (7.5\%). Araliaceae, Fabaceae, Meliaceae, Rosaceae, and Solanaceae contributed 2 genera each $(5 \%$ each). The remaining families of the study area are comprised of 1 genera each (Table 1).

Analysis of the habit of woody species recorded form Doshke forest revealed that the largest number of species 29 out of $44(66 \%)$ were trees, while $12(27 \%)$ were found to be shrubs and $3(7 \%)$ lianas (Figure 3 ).

3.2. Vegetation Classification. Four plant community types were recognized from hierarchical cluster analysis using PCORD version 5.0 computer program (Figure 4 ). The vegetation analysis was derived from the cover abundance data 
TABle 1: Plant families encountered in Doshke forest with their number of genera and species (\%=percentage contribution to the total).

\begin{tabular}{|c|c|c|c|c|}
\hline Family & No. of species & $\%$ & No. of genera & $\%$ \\
\hline Acanthaceae & 1 & 2.27 & 1 & 2.5 \\
\hline Aquifoliaceae & 1 & 2.27 & 1 & 2.5 \\
\hline Araliaceae & 3 & 6.82 & 2 & 5 \\
\hline Asparagaceae & 1 & 2.27 & 1 & 2.5 \\
\hline Asteraceae & 2 & 4.55 & 1 & 2.5 \\
\hline Celastraceae & 2 & 4.55 & 1 & 2.5 \\
\hline Dracaenaceae & 1 & 2.27 & 1 & 2.5 \\
\hline Ericaceae & 1 & 2.27 & 1 & 2.5 \\
\hline Euphorbiaceae & 3 & 6.82 & 3 & 7.5 \\
\hline Fabaceae & 2 & 4.55 & 2 & 5 \\
\hline Icacinaceae & 1 & 2.27 & 1 & 2.5 \\
\hline Lobeliaceae & 1 & 2.27 & 1 & 2.5 \\
\hline Meliaceae & 2 & 4.55 & 2 & 5 \\
\hline Melianthaceae & 1 & 2.27 & 1 & 2.5 \\
\hline Moraceae & 1 & 2.27 & 1 & 2.5 \\
\hline Myrsinaceae & 4 & 9.09 & 3 & 7.5 \\
\hline Myrtaceae & 1 & 2.27 & 1 & 2.5 \\
\hline Oliniaceae & 1 & 2.27 & 1 & 2.5 \\
\hline Phytolaccaceae & 1 & 2.27 & 1 & 2.5 \\
\hline Pittosporaceae & 1 & 2.27 & 1 & 2.5 \\
\hline Rosaceae & 2 & 4.55 & 2 & 5 \\
\hline Rubiaceae & 4 & 9.09 & 4 & 10 \\
\hline Sapindaceae & 1 & 2.27 & 1 & 2.5 \\
\hline Solanaceae & 2 & 4.55 & 2 & 5 \\
\hline Sterculiaceae & 1 & 2.27 & 1 & 2.5 \\
\hline Tiliaceae & 1 & 2.27 & 1 & 2.5 \\
\hline Urticacea & 1 & 2.27 & 1 & 2.5 \\
\hline
\end{tabular}

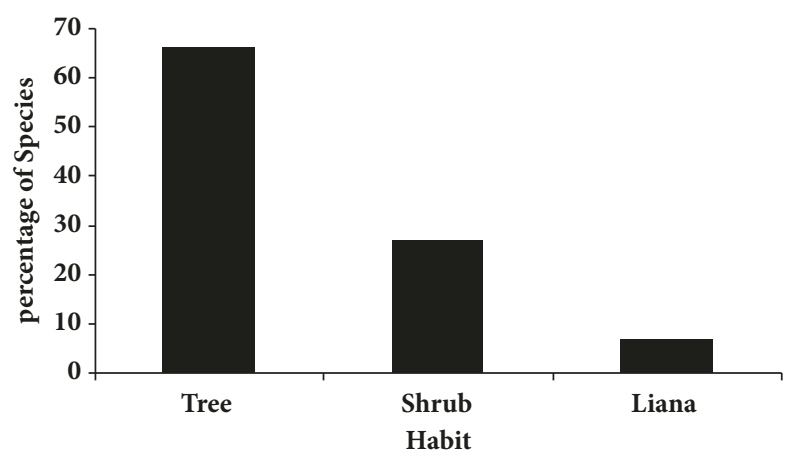

FIGURE 3: Distribution of plant species by their habits in Doshke forest.

matrix of 44 woody species by 42 plots from Doshke forest. The four community types obtained from the analysis were named after two or three characteristic species that had the highest mean cover abundance value (Tables $2-5$ ). The highest mean cover value that appears in their particular cluster was used as a criterion for giving name to these local vegetation communities. Accordingly, the four plant communities identified from the study area were Syzygium guineense-Galiniera saxiferaga community type (C1), Maesa
lanceolata-Allophylus abyssinicus community type (C2), Apodytes dimidiata-Maytenus undata community type (C3), and Syzygium guineense-Ilex mitis-Pavetta oliveriana community type (C4). In all observed plant communities, species with higher mean overabundance values are those that were easily observed repeating themselves in associations.

The four plant community types and their characteristics are listed and described in Figure 4. 


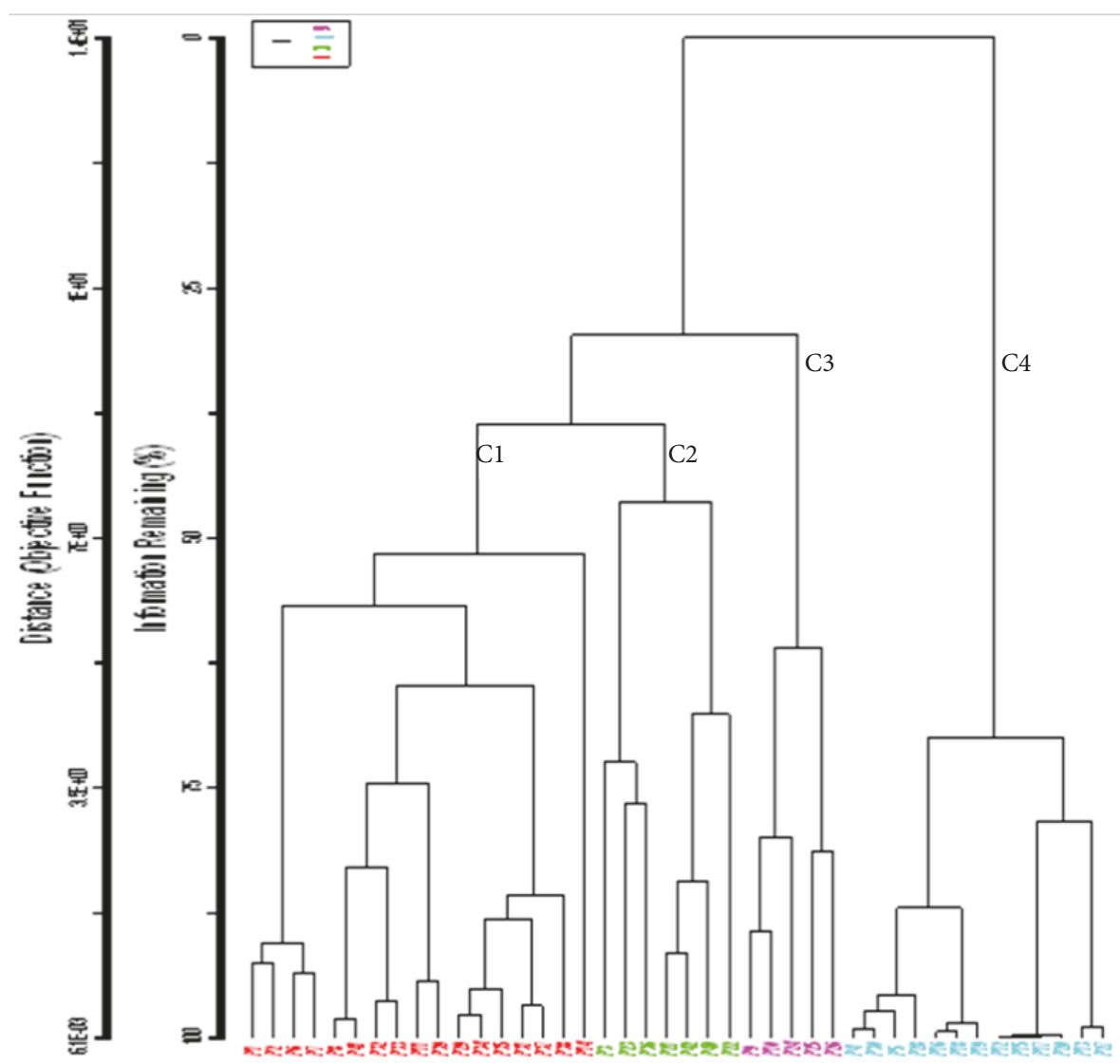

Figure 4: Dendrogram of the vegetation data obtained from hierarchical cluster analysis of Doshke forest $(\mathrm{C} 1=\mathrm{community}$ type $1, \mathrm{C} 2=$ community type $2, \mathrm{C} 3=$ community type 3 , and $\mathrm{C} 4=$ community type 4 ). $\mathrm{Cl}=$ Plots $1,2,6,7,8,41,32,33,11,39,29,34,35,31,37,38$, and 14 . $\mathrm{C} 2=$ Plots 3, 23, 36, 21, 42, 40, and 22. C3= Plots 9, 10, 24, 25, and 26. C4= Plots 4, 30, 5, 28, 16, 18, 19, 12, 15, 17, 20, 13 , and 27.

(1) Syzygium guineense-Galiniera saxiferaga Community Type. This community type is distributed between the altitudinal ranges of 2445 and 2517 m.a.s.l. in the forest. Compared to the rest three community types, it has the largest number of quadrats and species. It is represented by 17 plots and 40 species. The main associated characteristic and dominant species to this community are Syzygium guineense, Galiniera saxiferaga, Ilex mitis, Apodytesdimidiata, Maytenus undata, and Lobelia giberroa (Table 2). The other woody species associated with this community type include Dombeya torrida, Embelia schimperi, Lepidotrichilia volkensii, Pavetta oliveriana, Maesa lanceolata, Rubus apetalus, Croton macrostachyus, Allophylus abyssinicus, Erythrina brucei, Phytolacca dodecandra, Myrsine melanophloeos, Olinia aequipetala, and Ficus sur. Pittosporum viridiflorum, Erythrina brucei, and Polysphaeria parvifolia, are among the species which are found only in this community.

(2) Maesa lanceolata-Allophylus abyssinicus Community Type. This community types is distributed between the altitudinal ranges of 2431 and 2497 m.a.s.l. in the study area. This community resulted from 7 plots and 36 species. It is the second species rich community type. The most dominant species of this community type are Maesa lanceolata, Allophylus abyssinicus, Syzygium guineense, Galiniera saxiferaga, Rubus apetalus, and Discopodium penninervum (Table 3). The other characteristic species common to this community type including Schefflera abyssinica, Olinia aequipetala, Polyscias fulva, Maytenus undata, Agarista salicifolia, Urera hypselodendron, Vernonia myriantha, Ficus sur, Vernonia amygdalina, Triumfetta heterocarpa, and Sesbania sesban are common woody species of this community type.

(3) Apodytes dimidiata-Maytenus undata Community Type. The community type is encountered in the altitudinal ranges between 2457 and 2498 m.a.s.l. in the forest. It comprises smallest number of quadrats than the rest community types which is represented by 5 quadrats and 26 associated woody species. Along with the most dominant species used to name the community, Galiniera saxiferaga, Syzygium guineense, Ilex mitis, and Allophylus abyssinicus are the dominant species in this community type (Table 4 ). The other woody species associated with this community type include Discopodium penninervum, Euphorbia ampliphyla, Dracaena afromontana, Lobelia giberroa, Embelia schimperi, Maesa lanceolata, Acanthus eminens, Rubus apetalus, Polyscias fulva, Bersema abyssinica, Maytenus gracilipes, Pavetta oliveriana, Ficus sur, Dombeya torrida Lepidotrichilia volkensii, Triumfetta heterocarpa, and Ekebergia canpensis. 
TABLE 2: The top 6 plant species with the highest mean cover-abundance value in community type 1.

\begin{tabular}{lccc}
\hline No. & Scientific name & Mean cover abundance value & Proportion of plots in a community \\
\hline 1 & Syzygium guineense & 4.00 & 1.00 \\
2 & Galiniera saxiferaga & 2.18 & 1.00 \\
3 & Ilex mitis & 1.82 & 0.88 \\
4 & Apodytes dimidiata & 1.71 & 0.82 \\
5 & Maytenus undata & 1.59 & 0.94 \\
6 & Lobelia giberroa & 1.18 & 0.82 \\
\hline
\end{tabular}

TABLE 3: The top 6 plant species with the highest mean cover-abundance value in community type 2.

\begin{tabular}{lccc}
\hline No. & Scientific name & Mean cover abundance value & Proportion of plots in a community \\
\hline 1 & Syzygium guineense & 1.71 & 1.00 \\
2 & Galiniera saxiferaga & 1.57 & 1.00 \\
3 & Maesa lanceolata & 1.29 & 0.86 \\
4 & Allophylus abyssinicus & 1.14 & 0.71 \\
5 & Rubus apetalus & 1.12 & 0.71 \\
6 & Discopodium penninervum & 1.00 & 0.86 \\
\hline
\end{tabular}

(4) Ilex mitis-Pavetta oliveriana-Syzygium guineense Community Type. This community type is located between an altitudinal range of 2479 and $2551 \mathrm{~m}$.a.s.l. in the forest and comprised of 13 plots and 29 species. This community type is highly dominated by Syzygium guineense, Ilex mitis, and Pavetta oliveriana (Table 5). The other common woody species associated with this community include Galiniera saxiferaga, Maytenus undata, Lobelia giberroa, Embelia schimperi, Canthium oligocarpum, Acanthus eminens, Macaranga capensis, Schefflera abyssinica, Bersama abyssinica, Apodytes dimidiata, Asparagus africanus, Ekebergia capensis, and Acanthus eminens. Hypericum revolutum is among the species which are found only in this community type.

3.3. Species Diversity and Evenness of the Plant Communities. Shannon-Wiener diversity index and evenness were computed for the four communities from the vegetation data of Doshke forest (Table 6). Of the four community types, community type 2 exhibited the highest species diversity and evenness followed by community type 1 and community type 3. Community type 4 showed the least species diversity and evenness than others (Table 6). The least species diversity and evenness value of community type 4 may imply the dominance of the environment by few species. Reference [23], from his study on church vegetation, found different ShannonWiener diversity index and evenness for the communities he recognized, and he attributed low species diversity and evenness in a community to excessive disturbance, variable conditions for regenerations, and exploitation of some species.

While community type 1 had the highest species richness followed by community type 2 , community type 4 showed intermediate richness whereas community type 3 exhibited the least species richness (Table 6). The possible reason for high species richness of community 1 may be altitudinal factor because intermediate altitude could be associated with optimal conditions of environmental factors that favor vegetation growth. Furthermore, the most representative plots of this community are found far from anthropogenic disturbances such as agricultural expansion fire and fuel wood.

3.4. Similarity among Plant Community Types. The Sorensen's similarity coefficient was computed to detect dissimilarities among plant community types (Table 7). Based on this, similarity values in species composition between the communities ranged from 78 to $89 \%$. The highest similarity was observed between community type 1 (Syzygium guineense - Galiniera saxiferaga community type) and 2 (Maesa lanceolataAllophylus abyssinicus) (89\%) followed by community type 3 (Apodytes dimidiata-Maytenus undata) and 4 (Syzygium guineense-Ilex mitis-Pavetta oliveriana) (82\%). The least similarity was observed between community 2 and 4 (78\%), this may be due to conservational variation and variation in disturbance due to anthropogenic activities (Table 7).

\subsection{Vegetation Structure}

3.5.1. Height Distribution. For the description of the structure of Doshke forest, 44 woody plant species comprising 2164 individuals whose $\mathrm{DBH}$ are greater than $2.5 \mathrm{~cm}$ and height is greater than $2 \mathrm{~m}$ high were selected. Eight height classes were conventionally established (Figure 5). The height class distribution of trees and shrubs in this forest (Figure 5) indicated that more than $79 \%$ of the individuals have height less than $10 \mathrm{~m}$ (Height classes 1 and 2). Only small proportion, about $11 \%$, reached height up to $18 \mathrm{~m}$.

Generally, the density of each height class decreases with the increase in height showing an inverted J-shape pattern (Figure 5). The decreasing in density of each height class towards the highest height classes reveals the dominance of lower stature individuals in forest (Table 9). This could suggest that Doshke forest attributed to high rate of regeneration but poor recruitment which may be due to selective cutting 
TABLE 4: The top 6 plant species with the highest mean cover-abundance value in community type 3 .

\begin{tabular}{lccc}
\hline No. & Scientific name & Mean cover abundance value & Proportion of plots in a community \\
\hline 1 & Syzygium guineense & 3.80 & 1.00 \\
2 & Apodytes dimidiata & 3.00 & 1.00 \\
4 & Galiniera saxiferaga & 1.80 & 0.80 \\
5 & Allophylus abysinicus & 1.60 & 0.80 \\
6 & Ilex mitis & 1.20 & 0.60 \\
\hline
\end{tabular}

TABLE 5: The top 5 plant species with the highest mean cover-abundance value in community type 4.

\begin{tabular}{lccc}
\hline No. & Scientific name & Mean cover abundance value & Proportion of plots in a community \\
\hline 1 & Syzygium guineense & 6.15 & 1.00 \\
2 & Galiniera saxiferaga & 2.00 & 0.85 \\
3 & Ilex mitis & 2.00 & 1.00 \\
4 & Pavetta oliveriana & 1.62 & 0.85 \\
5 & Maytenus undata & 0.92 & 0.77 \\
\hline
\end{tabular}

or exploitation of bigger trees. Shrubs and small trees to be dominant in the floristic composition of Kimphe forest [24] and they suggested this is a consequence of selectively removal exploitation of bigger tree species.

Among different plant species, there are variations in height class distribution patterns. For example, Syzygium guineense and Galiniera saxiferaga showed an inverted J-shape pattern (Figures 6(a) and 6(c)), Ilex mitis (Figure 6(b)) showed a lower density in the first class followed by $\mathrm{V}$ shape pattern, and Apodytes dimidiata (Figure 6(d)) showed a higher density in the first class followed by irregular decrease or increase. These different distribution patterns of species occurred due to the nature of the species, regeneration capacity, and selective removal of individuals at specific size.

3.5.2. DBH Distribution. The woody plant species in the study area could be conveniently classified into eleven $\mathrm{DBH}$ classes: $2.5-12 \mathrm{~cm}, 12.01-24 \mathrm{~cm}, 24.01-36 \mathrm{~cm}, 36.01-48 \mathrm{~cm}$, $48.01-60 \mathrm{~cm}, 60.01-72 \mathrm{~cm}, 72.01-84 \mathrm{~cm}, 84.01-96 \mathrm{~cm}, 96.01-108$ $\mathrm{cm}, 108.01-120 \mathrm{~cm}$, and $>120 \mathrm{~cm}$ (Figure 7).

As the DBH classes size increases, the number of individuals gradually decrease beginning from 992 stems $^{-1}$ in the first class down to 15 stems ha ${ }^{-1}$ in the eleven $\mathrm{DBH}$ class. From the figure, it is also evident that about 992 (77\%) of the individuals ha ${ }^{-1}$ have $\mathrm{DBH}$ between $2.6-12 \mathrm{~cm}(\mathrm{DBH}$ class 1 ) and more than $1063(83 \%)$ of the individuals $\mathrm{ha}^{-1}$ have $\mathrm{DBH}$ less than $24 \mathrm{~cm}$ (DBH classes 1 and 2). The remaining $9 \mathrm{DBH}$ classes collectively account for about 225 (17\%) individuals $\mathrm{ha}^{-1}$. When viewed from the whole set of population structure, the distribution of all individuals in different size classes showed an inverted J shape for $\mathrm{DBH}$ classes (Figure 7).

The majority of the species had the highest number of individuals in the lower $\mathrm{DBH}$ and low in the high $\mathrm{DBH}$ classes. Such inverted J-shaped distribution pattern depicts that the forest is on the status of favorable regeneration potential. Similar results were reported by $[25,26]$ in their vegetation study. It is also noted that when the entire $\mathrm{DBH}$ class distribution of the forest is evaluated on a species basis, different distribution patterns for different species were revealed. For example, Syzygium guineense and Ilex mitis had almost an inverted J-shaped distribution pattern (Figures $8(\mathrm{a})$ and 8(b)), Galiniera saxiferaga had the highest number of individuals in the lower DBH class followed by irregular decrease up to the $7^{\text {th }}(72.01-84 \mathrm{DBH}$ class) but totally missed in the other left DBH classes (Figure 8(c)) and Apodytes dimidiata had the highest number of individuals in the lower $\mathrm{DBH}$ class followed by irregular decrease and increase but totally absent in the $9^{\text {th }}(96.01-108 \mathrm{DBH}$ class $)$ and again increase in the last two classes (Figure 8(d)). The inverted J-shape distribution pattern of Syzygium guineense and Ilex mitis may suggest that these species have a good reproduction and healthy regeneration potential in the forest. Similar result was reported by [27] for tree species from moist afromontane forest. In the case of Galiniera saxeferaga, the inverted J shape distribution pattern is terminated before reaching the higher $\mathrm{DBH}$ classes due to the shruby nature of the species. The irregularity of diameter classes of Apodytes dimidiata may indicate the selective removal of specific sized individuals.

3.5.3. Basal Area. The total basal area calculated for Doshke forest was about $103.7 \mathrm{~m}^{2} /$ ha for woody plant species $>2.5$ $\mathrm{cm}$ in $\mathrm{DBH}$. This is further partitioned into $1.2 \mathrm{~m}^{2} /$ ha for individuals with $\mathrm{DBH}$ between $2.5-12 \mathrm{~cm}, 2 \mathrm{~m}^{2} /$ ha for $\mathrm{DBH}$ $12.01-24 \mathrm{~cm}, 3.5 \mathrm{~m}^{2} /$ ha for DBH $24.01-36 \mathrm{~cm}, 3.7 \mathrm{~m}^{2} /$ ha for DBH 36.01-48, $6 \mathrm{~m}^{2} /$ ha for DBH $48.01-60 \mathrm{~cm}, 9.5 \mathrm{~m}^{2} / \mathrm{ha}$ for DBH $60.01-72 \mathrm{~cm}, 9.7 \mathrm{~m}^{2} /$ ha for DBH $72.01-84 \mathrm{~cm}, 13.5$ $\mathrm{m}^{2} /$ ha for DBH $84.01-96 \mathrm{~cm}, 10.5 \mathrm{~m}^{2} /$ ha for DBH $96.01-108$ $\mathrm{cm}, 22.3 \mathrm{~m}^{2} /$ ha for DBH $108.01-120 \mathrm{~cm}$ and $21.7 \mathrm{~m}^{2} /$ ha for $\mathrm{DBH}>120 \mathrm{~cm}$ (Figure 9). There is a considerable decrease in number of individuals with increasing DBH size and basal area. Individuals that attained higher $\mathrm{DBH}$ classes are fewer in number of individuals but higher in basal area.

A comparative contribution of the different DBH classes to the total basal area is presented in Table 2 and Figure 8. It is evident from the table that, even though about 992 (76.9\%) of all the individuals $\mathrm{ha}^{-1}$ had DBH less than $12 \mathrm{~cm}(\mathrm{DBH}$ class 1), the percentage contribution of this classes to the 
TABLE 6: Shanon-Wiener Diversity Index and Evenness of plant community types in Doshke forest (1=Syzygium guineense-Galiniera saxiferaga community type, $2=$ Maesa lanceolata-Allophylus abyssinicus Community type, $3=$ =Apodytes dimidiata-Maytenus undata Community type, and $4=$ Syzygium guineense-Ilex mitis-Pavetta oliveriana Community type).

\begin{tabular}{|c|c|c|c|c|c|}
\hline Communities & $\begin{array}{c}\text { Species } \\
\text { Richness }\end{array}$ & $\begin{array}{c}\text { Diversity } \\
\text { Index }\left(\mathrm{H}^{\prime}\right)\end{array}$ & $\begin{array}{l}H \max \\
(\ln S) \\
\end{array}$ & $\begin{array}{c}\text { Evenness } \\
\left(\mathrm{H}^{\prime} / \mathrm{H}^{\prime} \max \right)\end{array}$ & $\begin{array}{c}\text { Average } \\
\text { altitude }(\mathrm{m})\end{array}$ \\
\hline 1 & 40 & 2.98 & 3.69 & 0.81 & 2485.4 \\
\hline 2 & 36 & 3.04 & 3.58 & 0.85 & 2461.4 \\
\hline 3 & 26 & 2.62 & 3.26 & 0.80 & 2469.2 \\
\hline 4 & 29 & 1.82 & 3.37 & 0.54 & 2519.7 \\
\hline
\end{tabular}

TABLE 7: Sorensen similarity coefficient among community types.

\begin{tabular}{lcccc}
\hline Community types & 1 & 2 & 3 & 4 \\
\hline 1 & & $\mathbf{0 . 8 9}$ & 0.79 & 0.8 \\
2 & & & 0.81 \\
3 & & & 0.82 \\
4 & & & \\
\hline
\end{tabular}

total basal area was only $1.18 \%$. Conversely, the DBH classes greater than $108 \mathrm{~cm}$ (DBH class 10 and 11) had about 36.9 $(2.87 \%)$ individuals $\mathrm{ha}^{-1}$ of the total, but they contributed to about $42.42 \%$ of the total basal area computed for the forest (Table 8).

3.5.4. Vertical Stratification. The vertical structure of the woody species occurring in Doshke natural forest was described following the International Union Forestry Research Organization (IUFRO) classification scheme as used by [28]. The scheme classifies the storey into upper, where the tree height is greater than $2 / 3$ of the top height; middle, where the tree height is in between $1 / 3$ and $2 / 3$ of the top height and the lower storey where the tree height is less than $1 / 3$ of the top height. Accordingly, forest vegetation of Doshke forest was classified into three strata derived from the highest height of trees which was $40 \mathrm{~m}$. Consequently; the upper layer includes those individual tree species whose height exceeds $27 \mathrm{~m}$ while the middle stratum includes those individuals in between 13 and $27 \mathrm{~m}$, whereas the lower stratum comprises those plant species below $13 \mathrm{~m}$ (Table 9).

The result of the study indicated that the highest density $1101(85.5 \%)$ was attained by the lower storey individuals but only $130(10.1 \%)$ and $57(4.4 \%)$ density were exhibited by the middle and upper layer respectively. Similarly, more species were found in the lower storey but fewer species in the middle and upper storey (Table 9).

All of the plant species are found in the lower storey except two species Ekebergia capensis and Polyscias fulva which are found in the middle and upper storey. Nevertheless, there are many species, which could not attain the middle and upper storey by their nature. These species include Discopodium penninervum, Lobelia giberroa, Vernonia myriantha, Pavetta oliveriana, Maesa lanceolata, Vernonia amygdalina, Acanthus eminens, Solanum incanum, Rubus apetalus, Myrsine africana, Urera hypselodendron, and Asparagus africanus. The middle and upper layer of Doshke forest were occupied by species like Syzygium guieneense, Ilex mitis, Polyscias fulva, Ekebergia capensis, Apodytes dimidiata, Galiniera saxiferaga, Schefflera abyssinica, Ficus sur, and Hagenia abyssinica.

Generally, all the plant species that have representatives in upper layer also appeared in the middle and lower storey. Species of this kind are termed as species with regular vertical distribution [28].

3.5.5. Density and Frequency. The total density of woody plant species of Doshke forest with $\mathrm{DBH}>2.5 \mathrm{~cm}$ and height $>2 \mathrm{~m}$ is 1288 individuals per hectare. Out of these, 300 individuals/ha (23.3\%) are contributed by Syzygium guineense followed by Galiniera saxiferaga and Maytenus undata with 158.9 individuals/ha (12.3\%) and 148.2 individuals/ha (11.5\%) respectively. Similarly, Syzygium guineense is a frequently encountered species with frequency of $100 \%$ or relative frequency of $6.49 \%$ and followed by Galiniera saxiferaga and Maytenus undata with frequency of $97.62 \%$ and $95.24 \%$ or relative frequency $6.36 \%$ and $6.17 \%$, respectively (Table 10 ). Hence, these three species are the most densely and frequently occurring species of the study area.

3.5.6. Importance Value Index (IVI). Analysis of IVI revealed that the Doshke forest was highly dominated by 5 woody species: Syzygium guineense, Ilex mitis, Galiniera saxiferaga, Maytenus undata, and Apodytes dimidiata (Figure 10). Of these five species Syzygium guineense was the most important dominant species which contributed 88.01 (29.34\%) IVI value and followed by Ilex mitis and Galiniera saxiferaga with 22.32 (7.44\%) and 22.29 (7.43\%) IVI values, respectively. Maytenus undata and Apodytes dimidiata were achieved the fourth and fifth IVI rank with 17.99 (6.00\%) and 16.97 (5.66\%) IVI values respectively. The remaining species exhibited IVI values less than $9.71(3.24 \%)$ (Table 10$)$.

The greatest IVI reflects the extent of dominancy in a given species in relation to the other species in the structure 


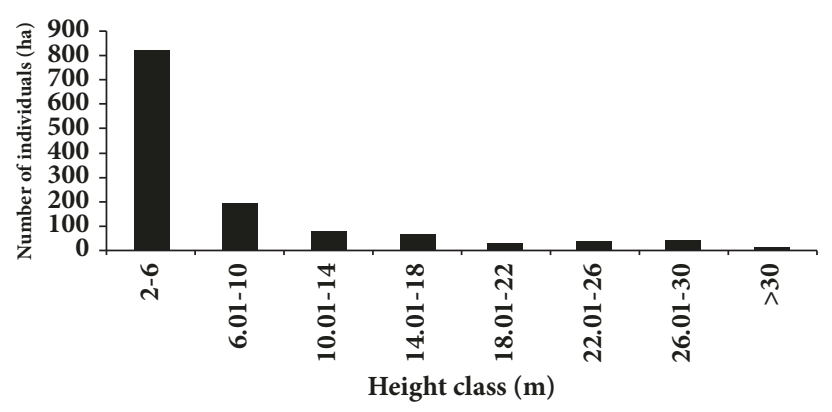

FIGURE 5: Height class distribution and number of individuals/ha of woody species in a forest.

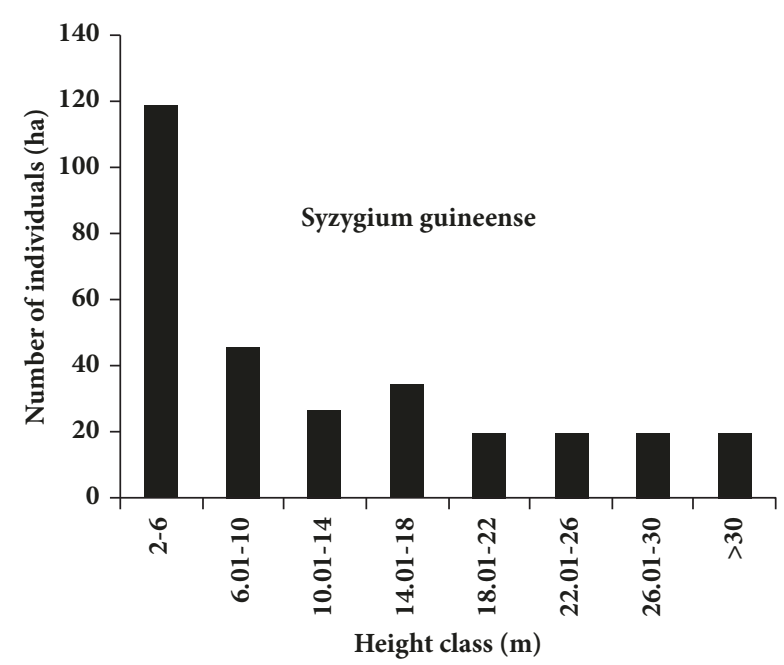

(a)

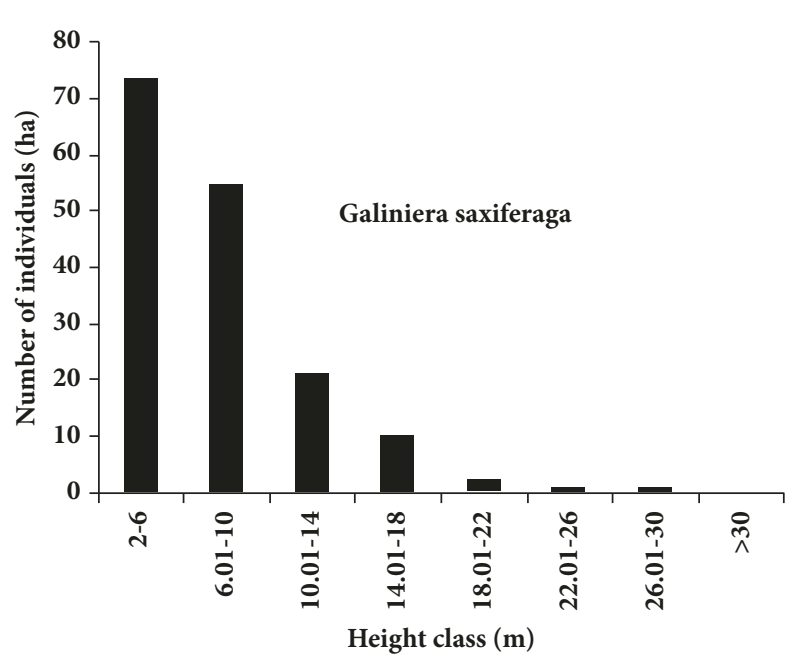

(c)

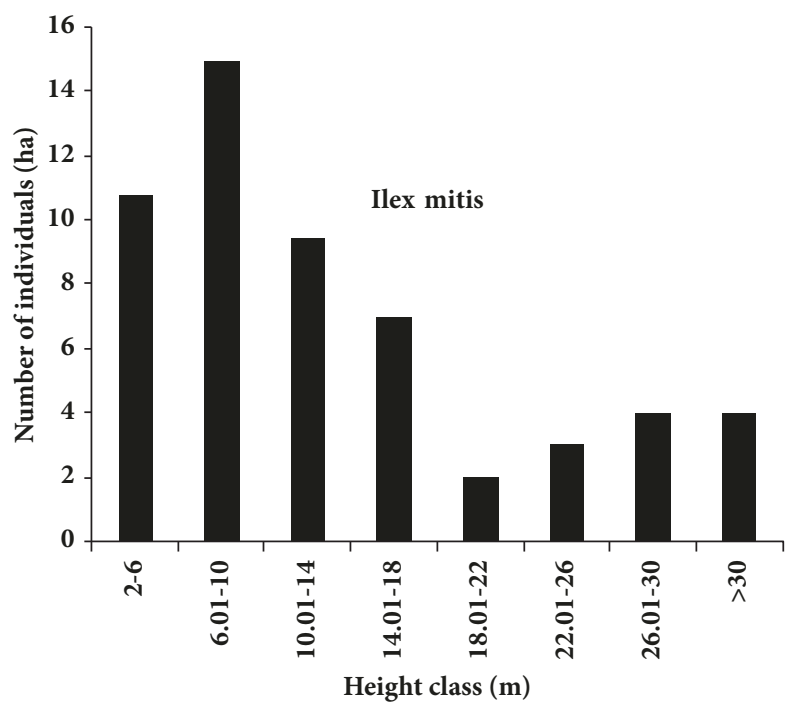

(b)

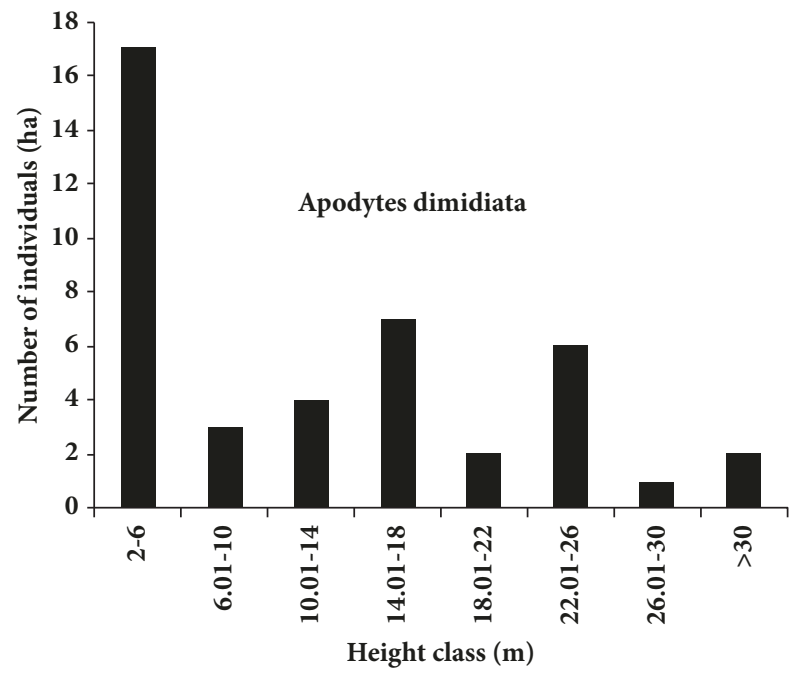

(d)

FIGURE 6: Height class distribution of some woody plant species of Doshke forest.

of a forest stand. According to [29], species with the greatest importance value index are the most dominant of the particular vegetation. It is also used for setting priority species management and conservation practices and helps to identify their sociological status in a certain plant species as dominant or rare species [18].

For the sake of setting species priority for conservation using IVI analysis all woody plant species encountered in 


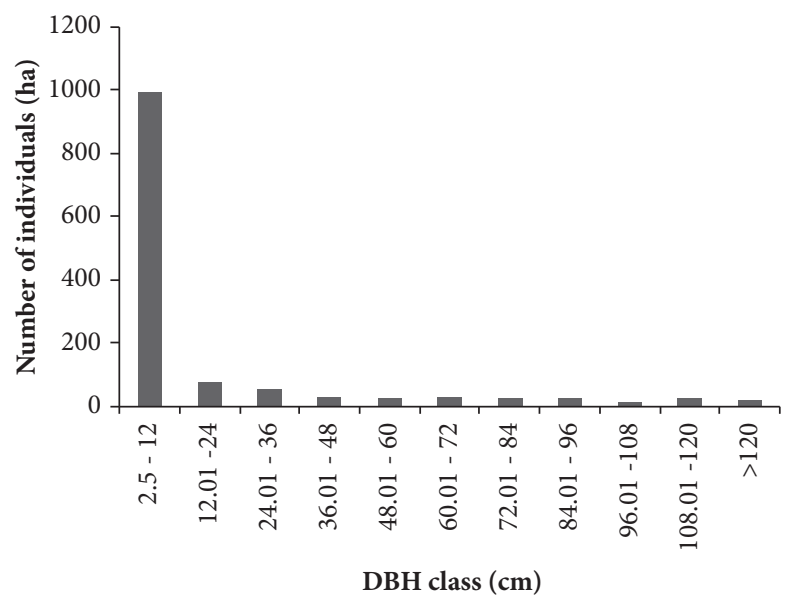

FIGURE 7: DBH class and the number of individuals/ha of woody species in Doshke forest.

TABLE 8: Contribution of different DBH classes to the total density and basal area $\mathrm{m}^{2} /$ ha in Doshke forest.

\begin{tabular}{|c|c|c|c|c|c|c|}
\hline No. & $\begin{array}{l}\text { DBH Class } \\
(\mathrm{cm})\end{array}$ & $\begin{array}{c}\text { Basal } \\
\left(\mathrm{m}^{2} / \mathrm{ha}\right)\end{array}$ & Area & $\%$ & Density (No of stems/ha) & $\%$ \\
\hline 1 & $2.5-12$ & 1.22 & & 1.18 & 992 & 76.99 \\
\hline 2 & $12.01-24$ & 2.00 & & 1.93 & 71.43 & 5.55 \\
\hline 3 & 24.01-36 & 3.49 & & 3.37 & 53.57 & 4.16 \\
\hline 4 & $36.01-48$ & 3.71 & & 3.58 & 26.79 & 2.08 \\
\hline 5 & $48.01-60$ & 5.99 & & 5.78 & 25.60 & 1.99 \\
\hline 6 & $60.01-72$ & 9.51 & & 9.18 & 27.98 & 2.17 \\
\hline 7 & $72.01-84$ & 9.70 & & 9.36 & 20.83 & 1.62 \\
\hline 8 & 84.01-96 & 13.51 & & 13.04 & 20.24 & 1.57 \\
\hline 9 & $96.01-108$ & 10.54 & & 10.16 & 13.10 & 1.02 \\
\hline 10 & $108.01-120$ & 22.30 & & 21.51 & 22.02 & 1.71 \\
\hline 11 & $>120$ & 21.67 & & 20.91 & 14.88 & 1.16 \\
\hline Total & & 103.65 & & 100.00 & 1288.10 & 100.00 \\
\hline
\end{tabular}

the forest were grouped into five IVI classes based on their total IVI values (Figure 10). Accordingly, 31 woody species are found to be with less than 7 IVI Value, 8 species with 7-14 IVI value, 4 species with 14-28 value ( IVI class 1421 and 21-28), and only 1 species with greater than 28 IVI value. Those species which exhibit lower IVI values need high conservation efforts while those with higher IVI values need monitoring management [30]. Accordingly, it can be recommended that those species which were grouped in IVI class $0.22-7$ need high conservation effort while those grouped in IVI class $>28$ need monitoring management.

Based on the IVI output, the following species accorded the highest priority for conservation efforts. These include Hagenia abyssinica, Urera hypselodendron, Vernonia myriantha, Lepidotrichilia volkensii, Euphorbia candelbrum, Maytenus gracilipes, Croton macrostachyus, Erythrina brucei, Agarista salicifolia, Solanum incanum, Polysphaeria parvifolia, Sesbania sesban, Myrsine melanophloeos, Asparagus africanus, Pittosporum viridiflorum, Myrsine africana, and Hypericum revolutum.
3.5.7. Regeneration Status: Species Composition and Density of Seedlings and Saplings. Composition and density of seedlings and saplings would indicate the regeneration status of the forest. The composition and density of seedlings and saplings of woody species in Doshke forest were investigated in this study. Accordingly, from the 44 representative woody species, a total of 24 species that belonged to 22 genera and 18 families were found to be represented in the seedling class. The total seedling density was $2312 \mathrm{ha}^{-1}$ which is about $(46 \%)$ of the total density of the vegetation.

The sapling class was composed of 25 species representing 24 genera and 19 families. The total sapling density was 1397 $\mathrm{ha}^{-1}(28 \%)$ of the total density of the vegetation and a total density of $1288 \mathrm{ha}^{-1}(26 \%)$ of the total density of the vegetation was contributed by mature plant species. Generally, the total density of all woody plant species (seedlings, saplings and matured species) recorded form the study area was $4997 \mathrm{ha}^{-1}$.

The ratio of seedlings to saplings was $1.7: 1$, seedling to the matured plant species was 1.8:1 and saplings to matured plant 


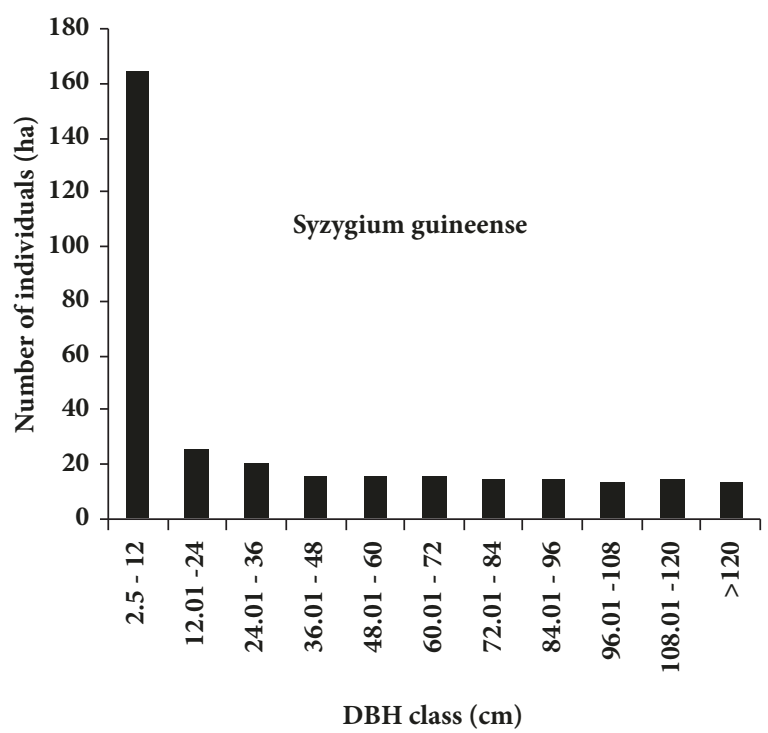

(a)

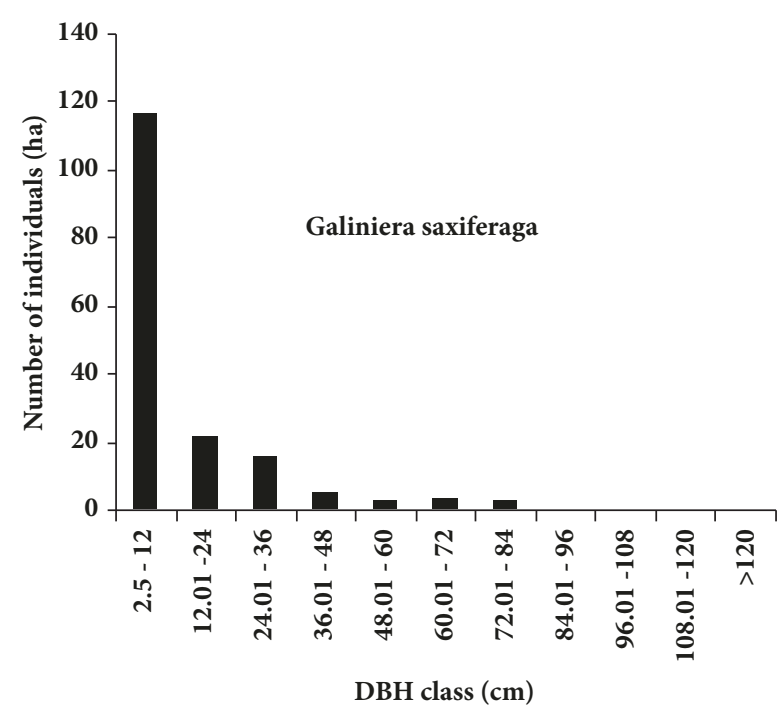

(c)

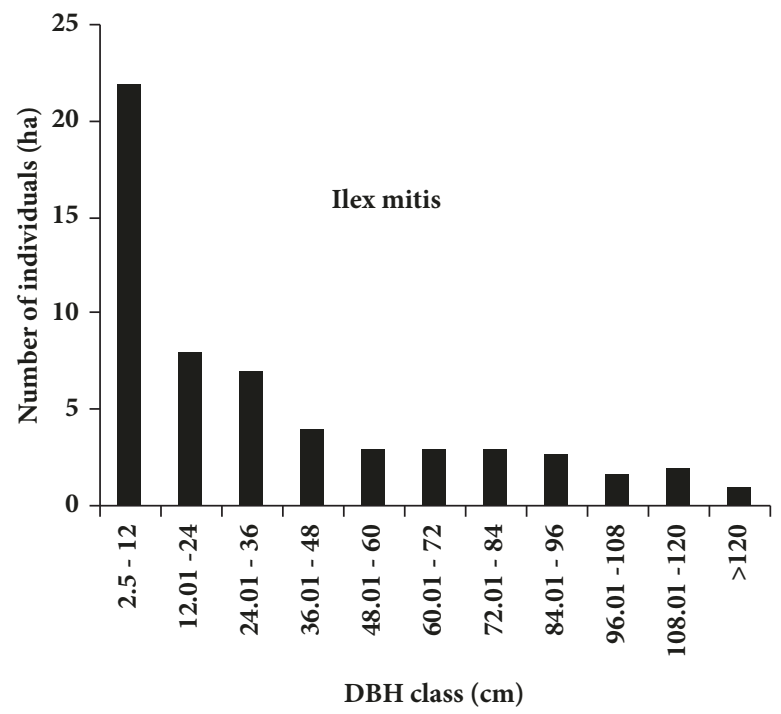

(b)

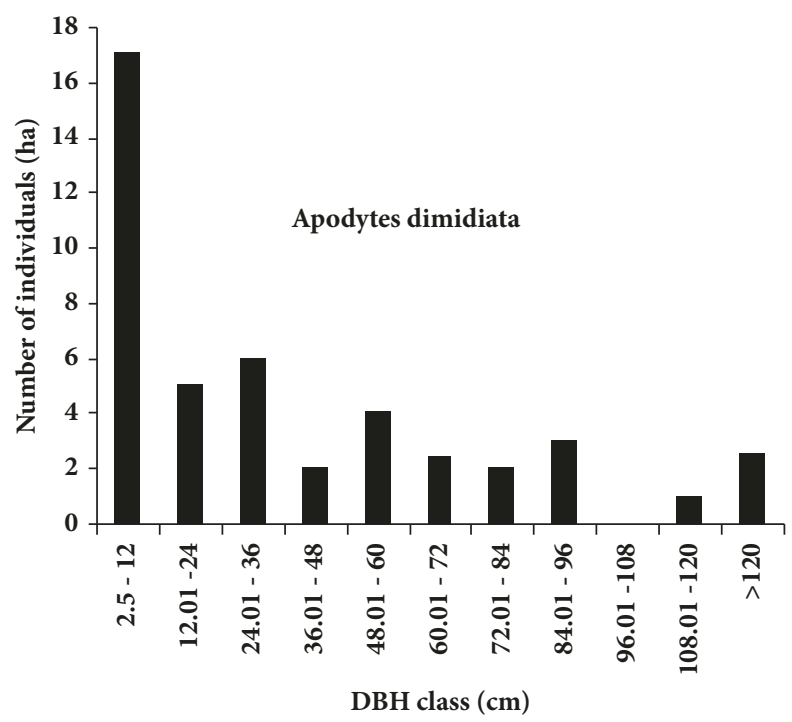

(d)

FIGURE 8: DBH class distribution of some woody plant species of Doshke forest.

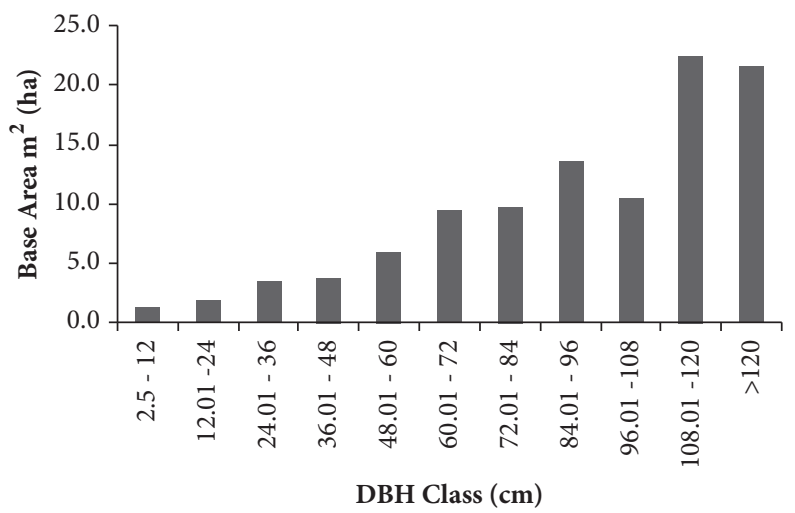

FIGURE 9: Basal area distribution over DBH classes of Doshke forest. 
TABLE 9: Density and number of woody species by storey in Doshke forest.

\begin{tabular}{lccccc}
\hline Storey & Height $(\mathrm{m})$ & $\begin{array}{c}\text { Number } \\
\text { of stems/ha }\end{array}$ & $\%$ & \multicolumn{2}{c}{ Number } \\
of species
\end{tabular}

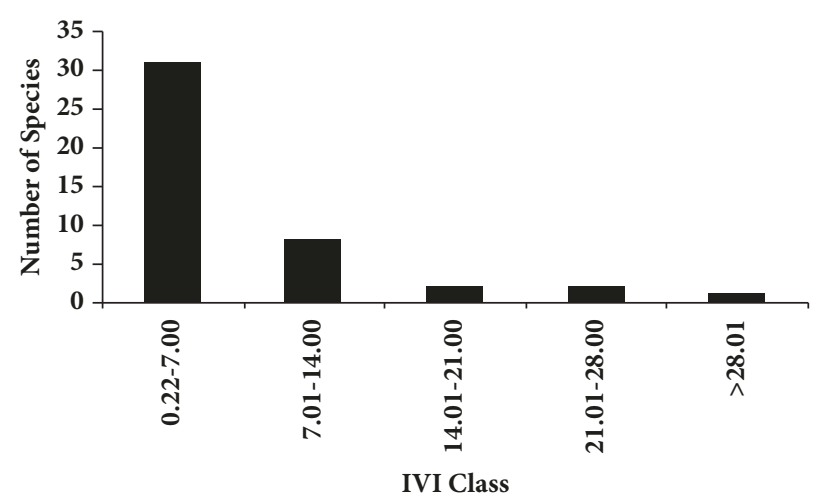

FIGURE 10: IVI classes and number of woody species in Doshke forest.

species was 1.1:1. These show that the distribution of seedlings as a whole is greater than that of saplings and matured plant species. The number of sapling individuals exceeds that of the matured individuals implying the survival of most seedlings to reach sapling stage.

The different woody species encountered in the forest have different density of seedlings and saplings. From the total woody plant seedlings (2312 ha $\left.{ }^{-1}\right)$, Embelia schimperi, Galiniera saxiferaga, Pavetta oliveriana, Allophylus abyssinicus, Lobelia giberroa, Bersama abyssinica, Maytenus undata, and Discopodium penninervum contributed $51.4 \%$ of the total seedling density. Syzygium guineense alone contributed high seedling density (43.6\%) to the forest. From the total woody plant saplings (1397 ha-1), Maytenus undata, Galiniera saxiferaga, Pavetta oliveriana, Discopodium penninervum, Allophylus abyssinicus, and Bersama abyssinica contributed $32.6 \%$ of the total sapling density. Furthermore, Syzygium guineense, Embelia schimperi, and Lobelia giberroa contributed $42.1 \%$, $11.8 \%$, and $9 \%$ of the total sapling density respectively. Most of the seedling and sapling densities are contributed by four species: Syzygium guineense, Embelia schimperi, Galiniera saxiferaga, and Lobelia giberroa. This shows that these species have high regeneration status.

Conversely, the seedling and sapling of some important species such as Hagenia abyssinica, Ekebergia capensis, Euphorbia ampliphyla, Dombeya torrida, Polyscias fulva, Olinia aequipetala, Ficus sur, Agarista salicifolia, Maytenus gracilipes, Schefflera abyssinica, Pittosporum viridiflorum, and Polysphaeria parvifolia are absent among the regeneration group. This may suggest that these species are either under threat of local extinction or may prefer coppices or sprouts as the strategy of survival. Thus, this situation calls for conservation measures through prioritization. To ensure this, the woody species of Doshke forest were grouped into three priority classes on the basis of their seedling and sapling densities following [31]. These are class 1 : those species with no seedlings and saplings, class 2: those with seedlings but no saplings, and class 3: those with both seedlings and saplings $\geq$ 1 individual/ha (Table 11). Accordingly, conservation activity should first focus on the species under Priority Class 1 and treat them as the first priority species to be conserved since they lack both seedlings and saplings. Priority Class 2 should come next and thirdly, class 3 is recommended to be given the appropriate conservation.

\section{Conclusions and Recommendations}

As determined through the present study, the floristic composition of Doshke forest consists of 44 woody plant species with the dominant families being Myrsinaceae and Rubiaceae. These dominant families might have well developed strategies and adaptations which helped them successfully to survive in the area. Since the collected woody species were composed of the highest number of trees, followed by shrubs and lianas, it can be generalized that the forest vegetation of the study area is dominated by the highest proportion of tree species.

The study has shown that the vegetation of study area was grouped into 4 plant community types each of which had varying degrees of species diversity and evenness. As the findings indicated that Syzygium guineense-Galiniera saxiferaga community type exhibited the highest species richness while the highest diversity and evenness were observed for Maesa lanceolata-Allophylus abyssinicus community type. Apodytes dimidiata-Maytenus undata community type had the least species richness while Ilex mitis-Pavetta oliveriana-Syzygium guineense community type was with the least species diversity and evenness. The evidence from this study suggests that the 
TABLE 10: The Importance Value Index (IVI) of woody plant species in Doshke forest.

\begin{tabular}{|c|c|c|c|c|c|}
\hline Species & $\begin{array}{l}\text { Relative } \\
\text { Density }\end{array}$ & $\begin{array}{l}\text { Relative } \\
\text { Frequency }\end{array}$ & $\begin{array}{c}\text { Relative } \\
\text { Dominance }\end{array}$ & I V I & $\begin{array}{l}\text { IVI } \\
\text { Rank }\end{array}$ \\
\hline Syzygium gueneense & 23.29 & 6.49 & 58.224 & 88.01 & 1 \\
\hline Ilex mitis & 4.30 & 5.71 & 12.310 & 22.32 & 2 \\
\hline Galiniera saxiferaga & 12.34 & 6.36 & 3.591 & 22.29 & 3 \\
\hline Maytenus undata & 11.51 & 6.17 & 0.317 & 17.99 & 4 \\
\hline Apodytes dimidiata & 3.28 & 4.48 & 9.210 & 16.97 & 5 \\
\hline Polyscias fulva & 1.57 & 3.70 & 4.428 & 9.70 & 6 \\
\hline Lobelia giberroa & 4.90 & 4.61 & 0.033 & 9.54 & 7 \\
\hline Maesa lanceolata & 3.84 & 4.81 & 0.555 & 9.20 & 8 \\
\hline Pavetta oliveriana & 3.84 & 4.81 & 0.050 & 8.69 & 9 \\
\hline Rubus apetalus & 3.79 & 4.61 & 0.252 & 8.65 & 10 \\
\hline Discopodium penninervum & 3.47 & 4.03 & 0.028 & 7.52 & 11 \\
\hline Embelia schimperi & 2.77 & 4.48 & 0.020 & 7.27 & 12 \\
\hline Ekebergia capensis & 0.46 & 1.36 & 5.212 & 7.04 & 13 \\
\hline Allophylus abyssinicus & 3.56 & 3.38 & 0.035 & 6.97 & 14 \\
\hline Schefflera abyssinica & 0.97 & 2.14 & 2.921 & 6.03 & 15 \\
\hline Bersama abyssinica & 2.59 & 3.25 & 0.031 & 5.87 & 16 \\
\hline Dracaena afromontana & 2.22 & 2.92 & 0.077 & 5.22 & 17 \\
\hline Ficus sur & 0.65 & 1.88 & 2.096 & 4.63 & 18 \\
\hline Dombeya torrida & 1.25 & 2.79 & 0.055 & 4.09 & 19 \\
\hline Olinia aequipetala & 0.83 & 2.34 & 0.013 & 3.18 & 20 \\
\hline Schefflera myriantha & 0.83 & 2.01 & 0.235 & 3.08 & 21 \\
\hline Triumfetta heterocarpa & 0.69 & 1.69 & 0.008 & 2.39 & 22 \\
\hline Canthium oligocarpum & 0.69 & 1.69 & 0.005 & 2.39 & 23 \\
\hline Macaranga capensis & 0.55 & 1.56 & 0.016 & 2.13 & 24 \\
\hline Vernonia amygdalina & 0.60 & 1.36 & 0.011 & 1.98 & 25 \\
\hline Acanthus eminens & 1.02 & 0.91 & 0.008 & 1.93 & 26 \\
\hline Phytolacca dodecandra & 0.42 & 1.23 & 0.003 & 1.65 & 27 \\
\hline Urera hypselodendron & 0.60 & 0.91 & 0.042 & 1.55 & 28 \\
\hline Hagenia abyssinica & 0.32 & 0.91 & 0.143 & 1.38 & 29 \\
\hline Vernonia myriantha & 0.37 & 0.91 & 0.003 & 1.28 & 30 \\
\hline Lepidotrichilia volkensii & 0.37 & 0.91 & 0.002 & 1.28 & 31 \\
\hline Euphorbia ampliphyla & 0.37 & 0.78 & 0.044 & 1.19 & 32 \\
\hline Maytenus gracilipes & 0.28 & 0.78 & 0.002 & 1.06 & 33 \\
\hline Croton macrostachyus & 0.32 & 0.65 & 0.005 & 0.98 & 34 \\
\hline Erythrina brucei & 0.18 & 0.65 & 0.001 & 0.84 & 35 \\
\hline Agarista salicifolia & 0.18 & 0.45 & 0.006 & 0.64 & 36 \\
\hline Solanum incanum & 0.14 & 0.32 & 0.001 & 0.46 & 37 \\
\hline Polysphaeria parvifolia & 0.09 & 0.32 & 0.002 & 0.42 & 38 \\
\hline Sesbania sesban & 0.09 & 0.32 & 0.001 & 0.42 & 39 \\
\hline Myrsine melanophloeos & 0.09 & 0.32 & 0.001 & 0.42 & 40 \\
\hline Asparagus africanus & 0.09 & 0.32 & 0.001 & 0.42 & 41 \\
\hline Pittosporum viridiflorum & 0.09 & 0.32 & 0.001 & 0.42 & 42 \\
\hline Myrsine africana & 0.09 & 0.13 & 0.001 & 0.22 & 43 \\
\hline Hypericum revolutum & 0.09 & 0.13 & 0.001 & 0.22 & 44 \\
\hline
\end{tabular}


TABLE 11: Woody species of Doshke forest categorized in to groups based on their order of conservation priority.

\begin{tabular}{lcc}
\hline Priority Class 1 & Priority Class 2 & Priority Class 3 \\
\hline Agarista salicifolia & Schefflera myriantha & Acanthus eminens \\
Dombeya torrida & Sesbania sesban & Allophylus abyssinicus \\
Ekebergia capensis & Triumfetta heterocarpa & Apodiytes dimidiata \\
Erythrina brucei & Vernonia amygdalina & Bersama abyssinica \\
Euphorbia ampliphyla & Vernonia myriantha & Croton macrostachyus \\
Ficus sur & & Discopodium penninervum \\
Hagenia abyssinica & Dracaena afromontana \\
\hline Maytenus gracilipes & & Embelia schimperi \\
Olinia aequipetala & & Galiniera saxiferaga \\
Pittosporum viridiflorum & Lepidotrichilia volkensii \\
Polysphaeria parvifolia & Lobelia giberroa \\
& Maesa lanceolata \\
& Maytenus undata \\
& Myrsine melanophloeos \\
& Pavetta oliveriana
\end{tabular}

variation in species composition and diversity among communities could be associated with different environmental and anthropogenic factors.

Generally, the density of tree species in the forest decreases with increasing $\mathrm{DBH}$ and height classes which implied the predominance of small sized individuals in the lower classes than in the higher classes. This also implied that the forest is in a good state of recruitment.

The study has shown that the total basal area calculated for Doshke forest was about $103.7 \mathrm{~m}^{2} /$ ha for woody plant species $>2.5 \mathrm{~cm}$ in DBH but most of the basal area was contributed by few large sized individuals. The study has found that generally, three layers of tree canopies were identified from the study of vertical stratification of Doshke forest. The highest number of stems and species were found in the lower storey but fewer in the middle and upper storey. Based on IVI output, the most dominant species are those that have the highest IVI value, as exhibited by Syzygium guineense, Ilex mitis, Galiniera saxiferaga, Maytenus undata, and Apodytes dimidiata.

In generally, the assessment of regeneration status based on seedling and sapling count revealed that a significant proportion of woody species were without seedling and sapling stage in the forest; some tree species are without sapling stage while others are represented by all stages. Based on this result the woody species of Doshke forest are grouped in to three priority classes for conservation.

Based on the findings of this study, the following recommendations are drawn so as to conserve the forest and assure the sustainability of services derived from it.

(i) The species in the first and second priority classes for conservation should be given appropriate attention and should be conserved in situ through the collaboration of local communities and the wereda Agriculture and Rural Development Office by designing an appropriate mechanism. (ii) Further investigation on the patterns of ecosystem functioning, the soil seed banks, germination performance of seeds, and establishment of seedlings should be conducted.

(iii) To find out the actual reasons for the absence of regeneration of plant species further investigation should be carried out.

(iv) Generally, the present study is limited to woody species composition, structure, and community types. Therefore, further studies on environmental parameters, none woody vegetation of the forest, soil seed bank, and regeneration of the species are recommended.

\section{Conflicts of Interest}

The authors declare that they have no conflicts of interest.

\section{Acknowledgments}

The authors would like to acknowledge the Ministry of Education and Arba Minch University for the financial support received through the Research Program. They are also grateful to Chencha Wereda Agricultural and Rural Development Office staffs and Doshke kebele elders for providing them necessary information about the wereda, their help in data collection, and provision of local plant names.

\section{References}

[1] T. Yohannes, T. Awas, and S. Demissew, "Survey and documentation of the potential and actual invasive alien plant species and other biological threats to biodiversity in Awash National Park, Ethiopia," Management of Biological Invasions, vol. 2, no. 1, pp. 3-14, 2011. 
[2] T. Abiyou, S. Teshome, K. Ensermu, and D. Abyot, "Floristic Composition and Community Analysis of Menagesha Amba Mariam Forest (Egdu Forest) in Central Shewa, Ethiopia," Ethiopian Journal of Biological Sciences, vol. 10, no. 2, pp. 111-136, 2011.

[3] L. Woldemichael, T. Bekele, and S. Nemomissa, "Vegetation Composition in Hugumbirda-Gratkhassu National Forest Priority Area, South Tigray," Momona Ethiopian Journal of Science, vol. 2, no. 2, pp. 27-48, 2010.

[4] S. Samson, B. Tamrat, and M. Alemayehu, "Floristic diversity and structure of nech sar national park, Ethiopia," Journal of the Drylands, vol. 3, no. 1, pp. 165-180, 2010.

[5] M. Yetebitu, E. Zewdu, and N. Sisay, "Manual for assessment and monitoring of carbon in forest and other land uses in Ethiopia," Tech. Rep., Ethiopian Forest Research Center, Addis Ababa, 2010.

[6] S. Teshome, T. Demel, and D. Sebsebe, "Ecological study of the vegetation in Gamo Gofa zone, Southern Ethiopia," Journal of Tropical Ecology, vol. 45, no. 2, pp. 209-221, 2004.

[7] S. Feyera and T. Demel, "Regeneration of Indigenous Woody Species in Native and Exotic Tree Plantations in Central Ethiopia," Tropical Ecology, vol. 42, no. 2, pp. 175-185, 2001.

[8] S. Feyera, "The Paradox of Forest Conservation and Food Security in Ethiopia," in Challenges Prospects of Food Security in Ethiopia, Tesfahun Fenta Osman Ali, Ed., pp. 317-328, The Paradox of Forest Conservation and Food Security, Ethiopia, 2004.

[9] B. Tamrat, Vegetation Ecology of Remnant Afromontane Forests on the Central Plateau of Shewa [Dissertation, thesis], Dissertation, Uppsala University, Ethiopia, 1994.

[10] I. Friis and T. Mesfin, "The evergreen forests of tropical Northeast Africa Dk-1123 Copenhagen K, Denmark," Opera Botanica, vol. 63, p. 1, 1990.

[11] D. Teketay, "Deforestation, wood famine, and environmental degradation in Ethiopia's highland ecosystems: urgent need for action," Northeast African Studies, vol. 8, no. 1, pp. 53-76, 2001.

[12] W. Tadesse and T. Demel, “The Forest Coffee Ecosystems: Ongoing Crises, Problems and Opportunities for Coffee Gene Conservation and Sustainable Utilization," in Imperative problems associated with forestry in EthiopiaWorkshop proceedings, pp. 131-142, Addis Ababa, 2001.

[13] J. L. Vivero, K. Ensermu, and D. Sebsebe, The Red List of Endemic Trees and Shrubs of Ethiopia and Eritrea, Fauna and Flora International, Cambridge, UK, 2005.

[14] S. Simon, "Contribution of Sacred Forest for Biodiversity Conservation: A case of Nagasa," in Proceeding of Workshop on Status Potentials and Challenges of Bio-cultural Diversity Conservation in Arba Minch University, SNNPR, pp. 21-26, 2008.

[15] RSA, Southern, Nations, Nationalities and Peoples Regional States Statistical abstract, 2007.

[16] O. Abera, Indigenous Common Grazing Land Management in Chencha Wereda, South Ethiopia. M.Sc Thesis, Addis Ababa University, 2006.

[17] J. Braun-Blanquet, Plant Sociology: the study of plant communities, Koeltz Scientific Books, Germany, 1965.

[18] D. Taylor, M. Kent, and P. Coker, "Vegetation Description and Analysis: A Practical Approach," The Geographical Journal, vol. 159, no. 2, p. 237, 1993.

[19] B. Mc Cune and J. Grace, Analysis of Ecological Communities, MjM Software Design, USA, p. 304, 2002.

[20] B. Mc Cune and M. Mefford, "Multivariate analysis of ecological data, PC-ORD," Window Version, 1999.
[21] A. W. Kuchler, D. Mueller-Dombois, and H. Ellenberg, "The Count-Plot Method and Plotless Sampling Techniques," in Aims and Methods of Vegetation Ecology, pp. 67-92, John Wiley and Sons, New York, NY, USA, 1974.

[22] C. E. Shannon, The Mathematical Theory of Communication, The University of Illinois Press, Urbana, Ill, USA, 1949.

[23] W. Alemayehu, Opportunities, Constraints and Prospects of the Ethiopian Orthodox Tewahido Churches in conserving forest resources, Swedish University of Agricultural Sciences, The case of Churches in south Gonder, north Ethiopia, 2002.

[24] B. Lenhard, A. Sandelin, L. Mendoza, P. Engström, N. Jareborg, and W. W. Wasserman, "Identification of conserved regulatory elements by comparative genome analysis," Journal of Biology, vol. 2, no. 2, article 13, 2003.

[25] Y. Kumelachew and B. Tamrat, "Plant community analysis and ecology of afromontane and transitional rainforest vegetation of Southwestern Ethiopia," SINET: Ethiopian Journal of Science, vol. 25, no. 2, pp. 155-175, 2002.

[26] S. Feyera, "Biodiversity and Ecology of Afromontane Rainforests with Wild Coffea arabica L. Populations in Ethiopia," in Ecology and Development Series No. 38, Center for Development Research, University of Bonn, 2006.

[27] D. Denu, Floristic Composition and Ecological Study of Bibita (Gura-Ferda) Forest, Southwest Ethiopia, M.Sc. thesis, Addis Ababa University, Ethiopia, 2006.

[28] H. Lamprecht, "Sericulture in the tropics. Tropical forest ecosystems and their Tree species possibilities and methods are the long-term utilization, T2-verlagsgeslls chaft," Sericulture in the tropics. Tropical forest ecosystems and their Tree species possibilities and methods are the long-term utilization, T2verlagsgeslls chaft, 1989.

[29] S. Simon and B. Girma, "Composition, Structure and Regeneration Status of Woody Species in Dindin Natural Forest, southeast Ethiopia: An Implication For Conservation," Ethiopian Journal of Biological Sciences, vol. 3, no. 1, pp. 15-35, 2004.

[30] D. Gemedo and S. Simon, Species Richness and Conservation Status of Some Ecologically and Economically Important Species in Sheko Forest, Institute of Biodiversity Conservation, Forest Genetic Resources Conservation Department, Ethiopia, 2007.

[31] F. Gurmessa, T. Soromessa, and E. Kelbessa, "Floristic Composition and Community Analysis of Komto Afromontane Moist Forest, East Wollega Zone, West Ethiopia," Science, Technology and Arts Research Journal , vol. 2, no. 2, p. 58, 2013. 


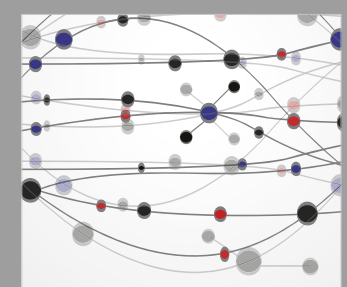

The Scientific World Journal
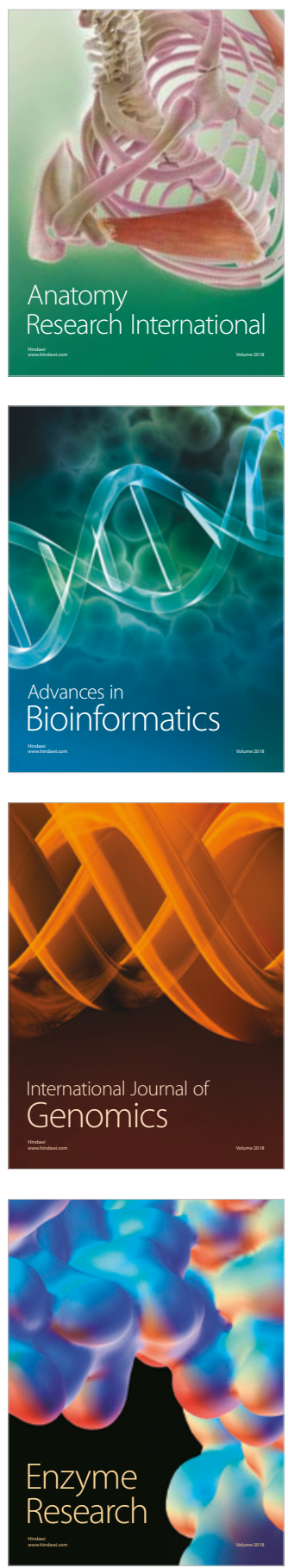
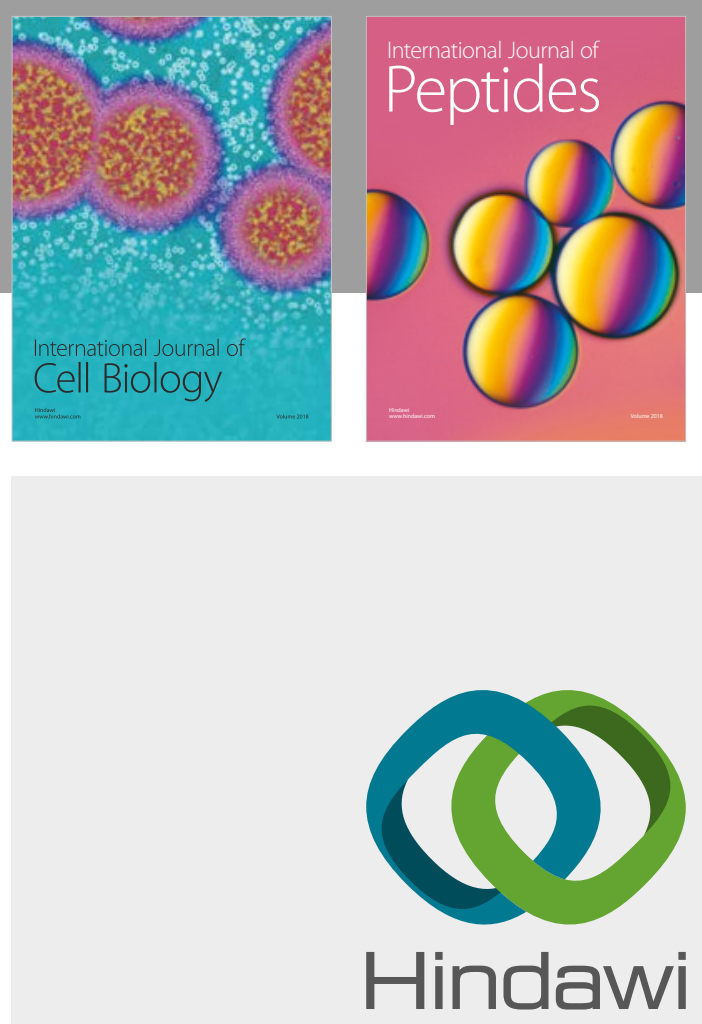

Submit your manuscripts at

www.hindawi.com
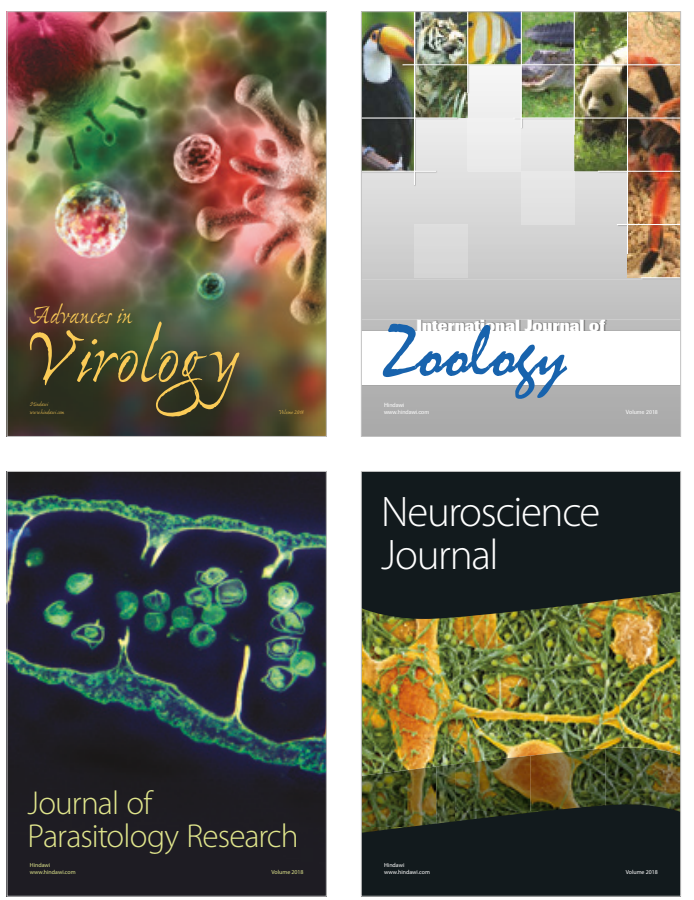
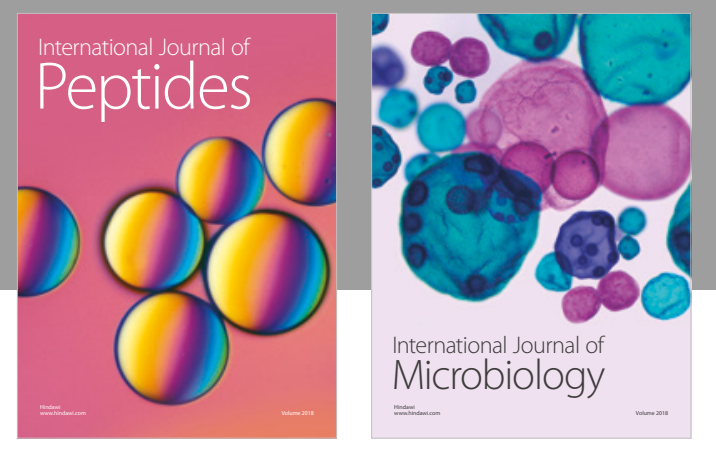

nternational Journal of Microbiology
Journal of
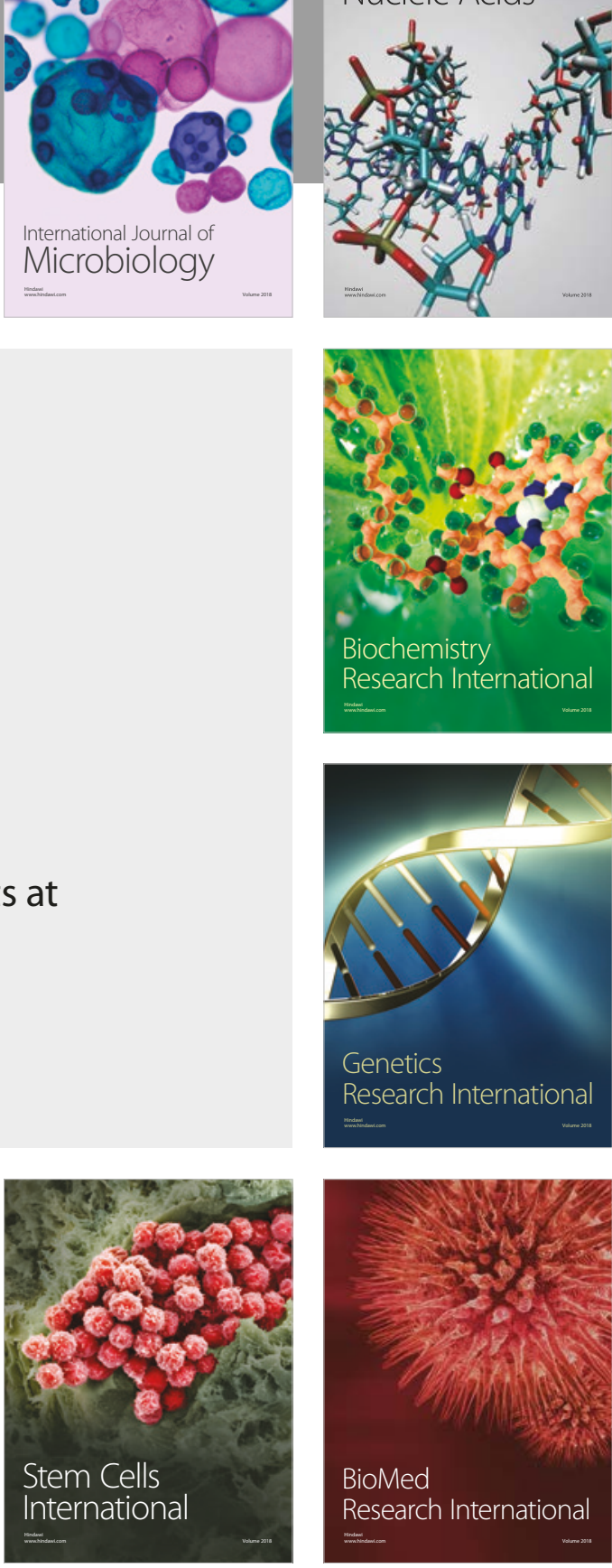
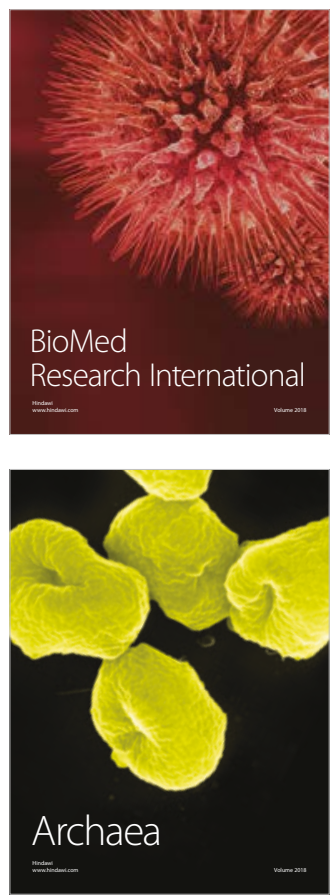